\title{
\begin{tabular}{llllllllllllllll}
$\mathrm{T}$ & $\ddot{U}$ & $\mathrm{R}$ & $\mathrm{K}$ & $\mathrm{T}$ & $\mathrm{A}$ & $\mathrm{R}$ & $\mathrm{I}$ & $\mathrm{H}$ & $\mathrm{K}$ & $\mathrm{U}$ & $\mathrm{R}$ & $\mathrm{U}$ & $\mathrm{M}$ & $\mathrm{U}$ \\
\hline \hline
\end{tabular} \\ BELLETEN
}

\section{ASUR TICARET KOLONILERI CAĞI'NDA ANADOLU KRALIÇELERI}

\section{REMZI KUZUOĞLU*}

M.Ö. II. binin ilk çeyreği Anadolu ile Asur arasındaki ticarî ilișkilerin en yoğun yașandığı dönemdir. Kuzey Mezopotamya'da, Dicle nehri kıyısında bulunan ve bugünkü Qal'at-Śirqāt'la aynı yer olduğu tespit edilen Asur șehri ile Anadolu'da Kayseri yakınlarındaki Kaniš șehri merkezli bu ticarî ilișki, yaklașıı 250 yıl sürmüștür. Asur Ticaret Kolonileri Cağı olarak da adlandırılan bu döneme âit bilgileri büyük çoğunluğu Kültepe/Kaniš’ te olmak üzere Boğazköy/Hattuš, Alişar ve Kaman-Kalehöyük'te ortaya çıkartulan ve bugün sayıları 20.000 'i așmıs olan Eski Asurca çivi yazılı belgelerden öğrenmekteyiz. M.Ö. 2000'lerde Anadolu'nun ve kısmen de olsa Asur'un siyasal, kültürel, sosyal, hukukî, ekonomik, tarihî, dinî ve coğrafî yapısı hakkında son derece önemli bilgiler veren Eski Asurca çivi yazılı bu belgeler, Anadolu'nun en eski yazılı kaynaklandır'.

Çalışmamızın ana konusunu teşkil eden Anadolu kraliçelerini ele almadan önce Anadolu ve Asur'da kadının sosyal statüsüne kısaca değinmekte fayda görüyoruz. Çivi yazılı belgeler bu dönemde, Asurlu kadınların aktif olarak ticaretin içinde bulunduklarını, mevki ve unvanlarının ticarî faaliyetlerine engel olmadığın², özellikle tekstil ve bira imalatında aktif olduklarını ve ürettikleri malların Anadolu'ya sevki safhasında önemli görevler üstlendiklerini göstermektedir. Aynı zamanda bu bayan-

* Gazi Üniversitesi, Sosyal Bilimler Enstitüsü, Eskiçağ Tarihi Bilim Dalı.

${ }^{1}$ Bizlere Anadolu'nun bu en eski yazılı belgeleri üzerinde çalıșma imkâm sağlayan merhum Hocamız Prof. Dr. Tahsin Özgüç'e ve bu gòrevi ondan devralıp, başarı ile sürdüren Prof. Dr. Fikri Kulakoğlu ve Kültepe kazı ekibine teșekkür ederim.

${ }^{2}$ Günbatu 1994, s. 191-200. 
lar, aile şirketlerinin Asur'daki temsilcisi, yöneticisi ve çalıșanı olarak da etkin bir rol üstlenmișler, kendi adlarına borç vermișler, senetler düzenlemişler, köle alıp-satmıșlardır. Mirastan pay alma hakkı bulunan" ve evlenme-boşanma durumunda sosyal hakları korunan Asurlu kadınlar sadece ev hanımı olarak değil, bașarılı bir iș kadını olarak da Asur toplumunun içinde yer almışlardır.

Bu dönemde Anadolu'ya baktığımızda ise, Anadolu kadınının sosyal statüsünün Asurlu hemcinslerinden daha aşağıda olmadı̆̆ı görülmektedir. Eldeki belgelere göre, Anadolu kadını en üst seviyede; ülke yönetiminde kral ile birlikte yan yana hatta bazı durumlarda tek başına görülür. Halk kadını olarak ise; ticaret yapmakta ${ }^{4}$, gayrimenkul ${ }^{5}$ ve köle alıp-satmakta', kendi adına senet düzenlemekte, nişanlanma, evlilik ve boșanma durumlarında sosyal hakları korunmaktadır ${ }^{7}$.

Sumerce'de GAŠAN, SAL.LUGAL ve UN.GAL ${ }^{8}$, Akadca'da šarratum kelimeleri "kraliçe" anlamı taşımaktadır". Eski Asurca'da ise rubātum kelimesi bu manaya sahiptir ve Anadolu kraliçelerine atfen kullanılmıştur ${ }^{10}$. Rubātum ve šarratum kelimeleri aynı manada olmalarına rağmen, aralarında, temsil ettikleri krallığın siyasi gücünden kaynaklanan bir statü farkı bulunmaktadır. Yani; rubā'um'un "müstakil kral", šarrum'un ise, "vasal kral" için kullanıldığını düşünürsek", rubātum kelimesi ile bağımsız bir ülkenin kraliçesinin kastedildiği anlaşılmaktadır.

Hitit dönemine baktığımızda ise, SAL.LUGAL/*haššuššara "kraliçe", SAL.LUGAL.GAL "büyük kraliçe" ve *tawananna "egemen kraliçe" tabirlerinin kraliçe kelimesinin karşılığında kullanıldıkları görülmektedir ${ }^{12}$.

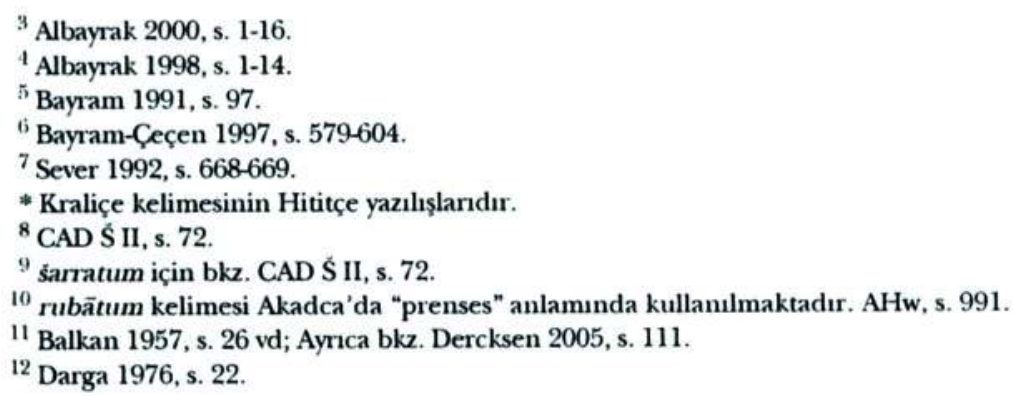


Konumuzla ilgili Türkçe en eski çalıșmalardan biri, "Eski Anadolu'da Kadın" adlı kitabı ile, M. Darga tarafından yapılmıșur ${ }^{1: 3}$. M. Darga, Koloni ve Hitit Cağı Anadolu kadın hakkında önemli değerlendirmeler yaptığı bu çalıșmasında, Koloni Cağı Anadolu kraliçelerini, "rubātum" bașlığı altunda ele almıștur. Biz bu makalemizde, M. Darga tarafindan değinilen belgeleri, kitabından sonra yayımlanmıș ve ilk olarak burada sunacağımız metinlerdeki" 'bilgiler ile bir arada ele alarak, günümüzden yaklașı 4000 yıl önce yaşamış ve o dönem Anadolu kadınımı en yüksek seviyede temsil eden kraliçeler hakkında yeni birtakım değerlendirmelerde bulunmaya çalıșacağız.

Sunacağımız ilk belge ${ }^{15}$, Anadolı sarayları ile yakın ilişki içinde olan, özellikle de kraliçelerin tekstil ihtiyacımı karșılayan "16 Ah-šalim adlı Asurlu tüccarın dört meslektașına yazmıș olduğu bir mektuptur. Muhtemelen Kültepe II. tabaka'nm ortalarında, yani M.Ö. \pm 1905-1860 arasında bir tarihte $^{17}$ yazılmış belgede, elbise ve kumaș sipariși veren Tawinia șehri's kraliçesinden bahsedilmektedir. Metinden ayrıca, bu bayanın eșinin, yani Tawinia kralının tahtta bulunduğu da anlașılmaktadır'.9. Konumuzla ilgili satırlarda: " kraliçenin sipariși olan bir beyaz elbise ve (bir) top ince kumașı bana gönder" denilmektedir"

Ah-šalim bir bașka mektubunda"1 yine bir kraliçenin kumaș siparişinden bahsetmektedir. Metnin akıșına göre, muhtemelen bugünkü Boğazköy ile ayıı yer olan Hattuš'un kraliçesi olan bu bayan, Tawinia

${ }^{13}$ Darga 1976.

11 Kendi arşivlerine ait belgeleri kullanmam hususunda gösterdikleri anlayıștan dolayı Hocam Prof. Dr. Sebahattin Bayram ve Prof. Dr. K. R. Veenhof'a teșekkürlerimi sunarum.

${ }^{15} \mathrm{Kt}$ n/k 388: Günbattu 1996, s. 30-31.

${ }^{16}$ Günbatt 1996 s. 32-33.

17 Ah-Śalim adlı tŭccarnn mektubunda hitap ettiği şahuslardan biri olan Usur-ša-Ištar'm, M.Ö. $\pm 1905-1860$ yılları arasında Anadolu'da ticari faaliyetlerde bulunduğu bilinmektedir. Bkz. Gökçek 2002, s. 59 vd.

${ }^{1 *}$ Kültepe metinlerinden bir kärum teșkilatuna sahip olduğunu bildiğimiz bu sehir. genellikle, Klasik dōnemdeki adı Tavium, modern adı Büyük Nefeskōy olan yere lokalize edilmektedir. Bkz. Nashef 1991, s. 116-117; del Monte-Tischler 1978, s. 417; del Monte 1992, s. 167.

\footnotetext{
${ }^{19} \mathrm{Kt} \mathrm{n} / \mathrm{k} 388$ : ") a-ru-ba-im ú me-er-i-śu ta-am-ni-a-i-im

${ }^{20} \mathrm{Kt} \mathrm{n} / \mathrm{k} 388:^{2 i)} 1$ TÚG lu-bu-ša-am ${ }^{2,5)}$ pá-Hi-am ù TÚG ku-ti-nam ${ }^{2+i)}$ qá-at-num ru-batum $2 \%)$ té-ri-ša-ni šé-bi,-lá-nim.

${ }^{21}$ Kt n/k 211: Günbatu 1996, s. 33, n. 5.
} 
kraliçesi gibi "ince kumaş" sipariș etmiștir. Metnin ilgi saturları şöyledir: "Kraliçe 2 top ince kumaşı sipariș etti" ".

TC 3, 161 nolu bir diğer metinde, Asanum ve Puzur-Aššur isimli Asurlu tüccarlara âit kumaşlarnn kraliçe için depo edildiği bilgisi mevcuttur. Metnin ilgili saturlarnnda: "Asanum'un 1 parça beyaz elbisesini (ve) Puzur-Aššrur'un 2 parça elbisesini kraliçe için taşıdılar" denmektedir". Yukarıdaki iki metinde olduğu gibi, bu metinde de kraliçe ve beyaz elbise bahsi bir arada geçmektedir. Buna göre, hem beyaz elbise hem de ince kumașın, bu dönem Anadolu saraylarmmn, özellikle de kraliçelerin vazgeçilmez tekstil ürünlerinin bașında geldiği görülmektedir.

Kültepe'de 1962 yılında ortaya çıkarılan arșive ait olmasından dolayı, yukarıda ele aldığımız üç metin ile aym döneme tarihleyebileceğimiz, çeșitli şahıslara ait kumaș miktarlarını gösteren $\mathrm{Kt}$ n/k 626 nolu metinde, sarayda bulunan kumaşların kraliçe tarafindan satun alındığı belirtilmektedir. Bu dönemde Asurlu tüccarlar ile Anadolu krallıkları arasında yapılan anlaşmalara göre; Asur'dan Anadolu'ya getirilen tekstil ürünlerinin ilk satun alma hakkmmn yerel saraylara âit oldığu bilinmekte$\operatorname{dir}^{24}$. Muhtemelen bu hakkı kullanan kraliçe, saraya getirilen kumașları ücretini ödeyerek satun almıștur. Metnin ilgili satırlan şöyledir: "Saraydaki 20 (top) kumașı fiyatı karșılığında kraliçe satın aldı"z:

Daha önce yaymlanmıș bir Kültepe tableti Wahšušanalı bir kraliçeden bahseder. Metindeki tarihleme, M.Ö. \pm 1872 yılına, yani Asur kralı NaramSuen zamanna ${ }^{2 i}$ denk gelir. Belgenin ilgili saturlarında: "Wahšušunalı kraliçe huzura kabul ettiği zaman bir parça kumaş ve bir parça šūrukumașı hediye olarak verdim" denilmektedir ${ }^{27}$. M. T. Larsen, hediyelerin veriliș sebebini kraliçenin huzura kabul etmesi olarak değerlendirmektedir" ${ }^{2 x}$.

${ }^{22} \mathrm{Kt} \mathrm{n} / \mathrm{k} 211{ }^{21)} 2 T \dot{U} G{ }^{25 i)}$ ku-ta-ni qá-at-nu-tim ru-ba-tum ${ }^{2(j)}$ té-ri-ši.

23 TC 3. 161: " 1 TÚG hu-bu-šu-um pá-și-um ") śa Asà-nim 2 TÚG lu-bu-ši "3) ša Puzur,-Ašùr a-ıu-ba-tim išsi $-\mathrm{i}$

${ }^{21}$ Larsen 1976, s. 245.

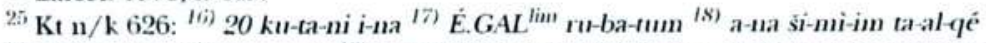

${ }^{25}$ KTS 1, 50c: ${ }^{11)}$ li-mu-um ${ }^{129}$ DUML Pá-pá-lim. Bu limum. Eski Asur krah Naram-Suen' in 1. hakimiyet senesinde görev yapmıșur. Bkz. Veenhof 2003, s. 9.

${ }^{27}$ KTS 1, 50c: ") i-nu-mi ru-ba-tum ") Wa-ah-šl-ša-na i-tù ${ }^{37}$ te-ru-ba-ni ${ }^{n} 1$ ku-ta-na-am

5) 1 TÚG š́t-ru-am "i) a-na ni-iše-em ") a-di-in.

${ }^{2 x}$ Larsen 1976 , s. 343. 
Metinlerde kraliçelerin tekstil ürünlerinin yannda, bakm ve gümus alacaklarıyla ilgili kayıtlar da mevcutıur. Bu ödemelerin kralicelerin bizıat katıldıklaır ticarî faaliyetlerin bì sonucu olan sahsî alacaklarmı mı, yoksa sarayın ihtiyacs olan bakı ve gümüs siparișlerini ni gösterclig̣i anlasslamamaktadır. Bu husustaki ilk belgemiz, Asurlu ve yerli șahslara ait bakır miktarlarmı gösteren bir listedir' Belgede yaklașı $18 \mathrm{~kg}$. bakım kraliçeye ait oldığu belirtihmektedir. Metuin ilgili satmmola, "I00 (mina bakn) kraliçe ile dir" demmektedir". Metinde, Nevșehir ve çevresinde ara

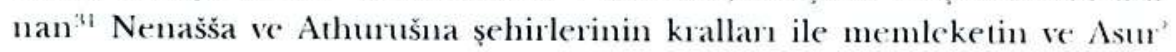
un beyleri gibi ifadelerin bulumması, bahsi geçen bu bayamm kaniš kraliçesi olma ihtimalini düșündürmektedir.

Kültepe'de ortaya (rkartılan bir belgede ${ }^{3 \%}$, II. katta (M.Ö. +1974-1835) wabartum ${ }^{33}$, Il katunda (M.Ö. 11800-1730) ise, kārum olarak adlandırılan ticaret merkezine sahip ${ }^{31}$ oldığumu bildiğiniz ve Mașat höyük yakınlanmola aranan Kuburnat selıri kraliçesinden bahscdilnektedir. Belgede yaklassk $240 \mathrm{gr}$. gümüsșün kıaliçeye, $2 \mathrm{~kg}$. gümüsșün ise memleketin bevine verildiği belirtilmektedir. Metnin ilgili satrrlar söyledir: " 8 l/3 mina gümüșï Ku bumat'a getirdiler. 1/2 mina gümüsü kraliçeve verdin, 1 mina gämüsü memleketin berine tattum ${ }^{* 36}$.

Asurlu tüccar Puzur-Ašsur tarafundan meslektașlan Idi-abum ve Ku lumäya yazılmıs bir mektupta:" kraliçeye ât miktarı belirtilmeven gümüșten bahsedilmektedir. Kaniš ile Wahšušana arasunda, muhtemelen kervanlarm güvenliğinin sağlanması hususunda yapılması beklene’n bir antlașmann da mevzu edildiği:* bu metinde: "klaliçenin ve knlat amirinin gümüșünü ödetsinler" denilmektedir ". Puzur-Asssur'un, Atata ve Aššsur-ma lik'e yazclığı bir diğer mektubunda ise, kraliçe ve kılar amiri gümüs

:" CCT VI. 34a: Ulshöfer 1995, s. 287.

"CCT VI, 34a: "i) I me-at KI ru-ba-tim.

31 Nashef 1991, s. 89: Bayam 1994, s. 212.

${ }^{32} \mathrm{Kt} 88 / \mathrm{k} 290$

33 Bavram 1994, s. 233.

$"$ Doubaz 2001, s. 106.

35 Alp 2001 , s. 49.

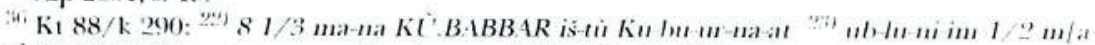

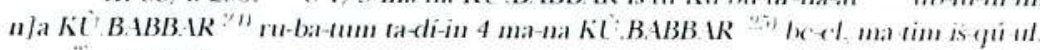

" $\mathrm{ATHE} 66$.

is Onlin 19\%0, s, 106.

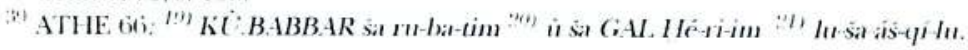


ödemesi ile alakalı olarak geçmektedir: "Puzur ${ }_{1}$-Aššur, Atata ve Aššurmalik'e şöyle der: Lütfen dikkat ediniz! Ve gümüsşü ya Kraliçenin ya (da) kırlar amirinin ödemesini sağlayını, ben gelemeyeceğim" "”.

Yayınlanmış bir Kültepe tableti" ${ }^{4}$, Asurlu tüccarların bir kraliçe ile olan yakın ilişkilerini göstermesi bakımından ilginçtir. Metinde, içeriği anlașılamayan bir belgenin kraliçeye teslim edilmesi ve bu belgenin kraliçe tarafindan korunması istenmektedir. Kraliçeye duyulan güvenin bir göstergesi olan bu istek, muhtemelen kraliçenin haberdar, belki de taraf olduğu bir durumdan kaynaklanmaktaydı. Kültepe II. tabakanın sonlarnna tarihleyebileceğimiz ${ }^{12}$ metnin ilgili satırlarında: "Bu belgeyi kraliçeye emanet edin ve onu muhafaza etsin" denilmektedir ${ }^{13}$.

Elimizdeki belgeler kraliçelerin emrinde olan bazı memurların varlığına işaret etmektedir. Bu hususta vereceğimiz ilk örnek" metinlerinden kalay ve kumaș ticareti ile tanıdığımız, Kayseri'nin güney veya güneydoğusunda aranan ${ }^{15}$ Timelkia șehri kraliçesi hakkındadır. Bir çeșit alacak-verecek kaydı olan ve M.Ö. \pm 1874 'e tarihleyebileceğimiz ${ }^{16}$ belgede, kraliçenin kılavuzuna ve kralın danıșmanına yapılan ödemelerden bahsedilmektedir. İlgili saturlarda șu ifadeler yer almaktadır: "1 1/3 mina kalayı kraliçenin kılavuzuna ödedim. 1/2 mina 5 šeqel kalay ve ticari malı kralın danışmanma verdim"17.

Bir diğer örnek ise, Aššur-malik adlı Asurlunun yine Asurlu olan Inā, Ennah-ili, Aššur-taklakı, Galgalia ve Nazi adı şahıslara yazdığı mektup-

${ }^{10}$ BIN 4, 93: ") um-ma Puzur $-A-$-šur-ma ${ }^{2)}$ a-na A-ta-ta-a ù "3) A-šur-ma-lik qi-bi-ma ") a-pu-

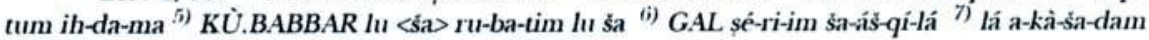

'Kt K0/k 332, 11'-12': Michel-Garelli 1997, s. 98.

${ }^{12}$ Metmin 15'. saturnda geçen En-um-A-šùr DUMU Sál-ma-A-š̀̀r șahıs adı, Kt 91/k 179'da li-mu-um I-na-a DUMU A-mu-ra-a; Kt 93/k 533'de ise, li-mu-um Bu-zu-ta-a ile birlikte kaydedilmiștir. Bu tarihleme Eski Asur krahı II. Puzur-Aššur'un 7 ve 8 . hakimiyet yıllarına denk düșmektedir. Bkz. Veenhof 2003, s. 9.

${ }^{13} \mathrm{Kt}$ 90/k 332: "1") DUB? a-nim / a-na ru-ba-tim ${ }^{\left.12^{\prime}\right)}$ pí-iq-da-ma / lu ta-Hú-ur.

${ }^{4}$ TC $3,211,44-45$.

${ }^{5}$ Nashef 1991, s. 119-120.

"1i TC 3, 211 nolu metnin 9. saturında geçen; ha-muš-tim ša Ha-na-na-ri-im șahıs adı, Kt 90/k 335'de (TPAK, s. 156) li-mu-um Bu-zu-ta-a ile birlikte kaydedilmiștir. Bu limum. Eski Asuı kralı Puzur-Aššur'un 7. hakimiyet yılında, yani M.Ö. \pm 1874 'te göres yapınıșur.

${ }^{17}$ TC 3, 211: ${ }^{15)}$ a-na ra-di-im ša ru-ba-tim áśsuúl ${ }^{16)} 1 / 2$ ma-na 5 GÍN AN.NA ú sà-he-ertám ${ }^{17)}$ a-na ma-li-ki-im ša ru-ba-im ${ }^{48)}$ a-dí-in. 
tur $^{\text {'s }}$. Belgede, bir kraliçenin çobanının gümüș ve buğday borçlarından bahsedilmektedir. İlgili satırlarda: "Kraliçe'nin çoban (olan) Hapuala, 12,5 mina gümüș ve 100 çuval buğdayı bana borçludur" ifadeleri kayıthidır".

Hapuala şahıs adına bașka bir metinde ${ }^{\text {nto }}$, muhtemelen Kaniš șehri kraliçesi olan bir bayanın emrinde bulunan Alahinnum görevlisis ${ }^{\text {II }}$ olarak rastlamaktayız. Yukarıdaki belgede geçen şahısla, sadece isim benzerliği olan Alahinnum Hapuala'nun, "at" olduğu kabul edilen " "perdum"un bedelini elinde tuttuğu anlașılmaktadır. İlgili saturlarda: "perdum'un bedeli olan 4 mina gümüş kraliçenin alahinnum'u olan Hapuala'dadır" denmektedir ${ }^{53}$. Bu belgenin dublikatında ise, Kraliçenin emrinde bulunan sofracılar amirinden bahsedilmektedir. Belgede: "12 šeqel gümüș kraliçenin sofracı amiri Karia'dadır" denilmektedir ${ }^{54}$. Her iki metinde geçen hamuštum isimleri dikkate alındığında, bahsi geçen kraliçenin, en azından M.Ö. \pm 1868 ile 1856 yılları arasında Kaniš tahtunda bulunduğu anlașilmaktadır ${ }^{55}$. Ayrıca, hem alahinnum hem de sofracılar amiri olan yerel görevlilerin kraliçenin emrinde bulunmaları, bu tarihlerde Kaniš memleketini yöneten kral ve kraliçenin bazı durumlarda (hastalık, savaș, vb.) birtakım idari yetkileri paylașmıs olmalarıyla da açıklanabilir.

Bugünkü Alișar ile bir tutulan Amkuwa șehrinde ortaya çıkarılan, Kültepe Ib tabakası ve Asur kralı I. Šamši-Adad dönemi ile çağdaş Nabi-

${ }^{48}$ ICK $1,13$.

49 ICK 1, 13: ${ }^{5)} 12$ 1/2 ma-na KU்.BABBAR ù 1 me-at na-ru-uq ${ }^{\text {(i) }}$ sé-am Ha-pu-a-lá re-i-um 7) sa ru-ba-tim ha-bu-lam

${ }^{50)} \mathrm{Kt} \mathrm{m} / \mathrm{k}$ 24, 13-14: bu metnin duplikat olan $\mathrm{Kt} \mathrm{m} / \mathrm{k} 35,12-13$.

${ }^{5} \mathrm{CAD}$ A, s. 294'de "an administrative official" anlamı verilen bu kelimeyi Veenhof 2006, s. 779'da, "steward " olarak değerlendirmektedir.

${ }^{52}$ Sugiyama 1997, s. 139-154; Michel 2003, s. 190-200.

${ }^{53} \mathrm{Kt} \mathrm{m} / \mathrm{k}$ 24: ${ }^{12)} 4$ ma-na KU்.BABBAR Śí-i[m] ${ }^{133}$ pè-er-de se KI Ha-pu-a-lá [a-lá-hi-nim] 14) sa ru-ba-tim, Kt m/k 35: ${ }^{\text {12) }} 4$ ma-na KÙ.BABBAR śi-im pè-er-de se e liz) KI Ha-pu-a-lá a-lá-hi$<$ ni>im ša ru-ba-tim

${ }^{54} \mathrm{Kt} \mathrm{m} / \mathrm{k}$ 35: ${ }^{23)} 12$ GÍN KÙ.BABBAR ${ }^{21)}$ KI Kà-ri-a GAL pá-šl-ri ša ru-ba-tim.

${ }^{55} \mathrm{Kt} \mathrm{m} / \mathrm{k} 24$ ve bu metnin dublikatı olan $\mathrm{Kt} \mathrm{m} / \mathrm{k} 35$ 'te geçen ha-mu-uś-tim ša Lu-z[i-na], CCT 1,2 ve POAT 4'de li-mu-um ša qá-tí A-gus -tim ile birlikte geçmekte ve bu tarihleme Asur krah Naram-Suen' in 5 . hakimiyet yılım, yani M.Ö. $\pm 1868^{\prime}$ e denk düșmektedir. ha-mu-ıĹ-tim ธ̌a

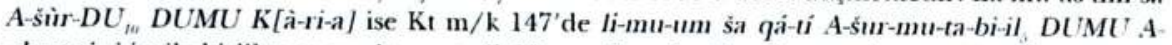
$<$ bar >zi-zi-im ile birlikte geçmekte ve tarih Naram-Suen'in 17, saltanat yılıa, yani M.Ö. + 1856'vı göstermektedir. 
Enlil adlı Asurlunun arşivine âit bir mektupta ${ }^{5 \hbar j}$, Amkuwa șehrinin, bir kraliçe ve "merdiven büyüğü" olarak tercüme edilen rabi simmiltim tarafından idare edildiği kabul edilmektedir ${ }^{57}$. Belgede kraliçe ve rabi simil tim'den, tutuklanmıs olan Šalahšua sarayının Hapirularının serbest bırakılmaları istenmektedir. Kraldan değil de kraliçe ve rabi similtim'den böyle bir talepte bulunulması, bu dönemde Amkuwa'nın bir kraliçenin idaresi altuna olması ile açıklanmaktadır"s8. Belgede; "Hapiste tutulan S̆alahšua saraymm Hapiru adamlan hakkında ben sana yazdın. Git! Ve Kraliçe ve rabi similtim'in ağzmı araștur. Eğer kraliçe ve rabi similtim onlan serbest birakırlarsa bana yaz"

Elimizdeki birkaç belge, kral ve kraliçelerin birlikte hareket ettiklerini göstermesi bakımmndan mühimdir. Bu belgelerden ilkinde ${ }^{i 0}$ muhtemelen Kaniš șehrinin idarecileri olan kral ve kraliçe, yerli bir aileyi Asurlu bir şahsa satarlarken görülmektedir. Belgedeki tarihlemeye göre ${ }^{\text {til }}$ bu sauș, Asur kralı Naram-Suen'in 8. hakimiyet yılında, yani M.Ö. \pm 1865 'te gerçekleșmiștiri? ${ }^{4}$. Bu tarih, yukarıda değindiğimiz alahinnum ve sofracılar amirinin kraliçesi olan bayanm Kaniš tahunda oturduğu dönemle aynı görünmektedir. Buna göre, her üç metinde bahsi geçen kraliçe aymı șahıs olmalıdır. İlgili satırlarda şöyle denilmektedir: "Kral ve kraliçe, Karia, onıu karısı ve onun oğullarını [40] mina gümüss karşılığında Itür-ili'ye verdiler ${ }^{\text {mis }}$.

Kral ve kraliçenin birlikte amıldığı bir diğer belge, Anadolulu şahıslar arasında düzenlenmiş bir borç mukavelesidir ${ }^{\text {tit }}$. Muhtemelen Kültepe II. tabakaya ait bu metinde, borcun ödeme tarihi kral ve kraliçenin yemin ettikleri zamana göre düzenlenmiștir. Vadelendirme tabiri olarak kullanılan ifadelerden, kralların Tanrı Ana ve Nipas'm mabetlerinde dini törenlere

54. OIP 27, 5.

i7 Balkan 1957, s. 54-55.

is Darga 1976, s. 6.

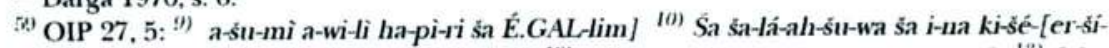
im] ${ }^{11)}$ [wa]-ás-bu-ni áś-pu-ra-ku-um a-[li-ik-ma] ${ }^{12)}$ [pi]]-i nu-ba-ú ú GAL si-[mi-il,-tim] ${ }^{133)}$ [š]aa-al-ma šu-ma ru-[ba-tum ú GAL si-mi-ils-ti] ${ }^{\text {It) }}$ î-ta-ru-šu-nu śu-up-r[a-am].

${ }^{606}$ KTK 106.

${ }^{61}$ KTK $106:^{97)}$ li-mu-inm ${ }^{\text {(i) }}$ S[a2]!-ma

12 Veenhof 2003, s. 9.

6i. KTK 106: " [a-na 40] ma-na KÙ.BABBAR Kà-ri-a " [a-ša]-sú ì me-ere-sü "3) ru-ba-um / ú ru-ba-tum " a-na I-tur,-DINGIR/i-di-nu.

${ }^{\text {ith }} \mathrm{Kt} 91 / \mathrm{k}$ 282. Bu metin K. R. Veenhof tarafindau yaymlanacakur. 
katıldıklarını $^{t \bar{x}}$ ve yemin ettiklerinititi bilmemize rağmen, kraliçelerin de kral ile birlikte yemin ettikleri hususu ilk olarak bu metinde görülmektedir. İlgili satırlar șöyledir: "5 mina gümüșü onlar adlma o ödedi. Kral ve kraliçe Tanı Ana'nu huzurunda yemin ettiler"miz.

Kültepe'de yapılan arkeolojik kazılar M.Ö. \pm 1835 'lerde Kaniš șehrinin maruz kaldığı büyük bir yıkıma ișaret eder ${ }^{\text {iti }}$. Bu dönemde șehir büyük bir yangın geçirmiş, bunun sonucu olarak Anadolu ile Asur arasındaki ticaret yaklașık 35 yıl sürecek ${ }^{69}$ bir duraklama dönemine girmiștir. Ayrıca, çivi yazılı belgelerde kayıtlı; isyanlar, iç huzursuzluklar ve savașlarla ilgili ifade$\operatorname{ler}^{70}$ Kaniš șehrine yaklașan bu tehlikenin varlığına da ișaret etmektedir.

Kültepe'de 1983 yılı kazılarında bulunan bir tablet yukarıda bahsettiğimiz isyanlardan biri hakkmdadır ${ }^{71}$. Bugünkü Gürün'e lokalize edi$\operatorname{len}^{72}$ Tegarama șehri kārumundan muhtemelen Kaniš karumuna yazılmıș olan bu mektupta, memleketin isyan halinde olduğu belirtilmektedir. Belgede ayrıca, Kaniš kralı ve kraliçesinin durumlarından da bahsedilmektedir. Fakat ilgili kısmın kırık olmasından dolayı, kral ve kraliçenin içinde bulundukları durum hakkında bir bilgi edinememekteyiz. Ancak, metnin devammda belirtilen memleketin isyan halinde bulunduğu ifadesi, kral ve kraliçenin pek de iyi bir durumda olmadıklarmı göstermektedir. Bı olay muhtemelen II. katın sonlarına doğıu vuku bulmuș olmalıdır. Cünkï Tegarama șehrinde bulunan Asur ticaret merkezi II. katta kārum, Ib katunda ise wabartum düzeyindedir. Mektubun Tegarama kărumundan yazılımıș olması sebebiyle bu olayın II. katta, yani M.Ö. $\$ 1835$ 'lerden önce gerçekleşmiș olması gerekmektedir. Metinde şöyle denilmektedir: "[Kaniš kārumuma ?] Tegarama kärumu şöyle der: İșitiyoruz ki kral ve kraliçe [zor durumdadır! ?] Sizler babamı beylerimizsiniz! Beylerimiz! Memleket isyan halindeyken sizin bulunduğunuz yere yazdık. Habercilerimiz Aššurnädā ve

(i) Ceçen 1998, s. 119 vd.

ini ICK 1, 32.

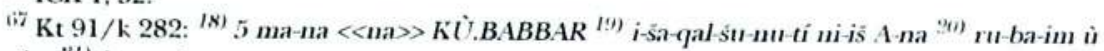
mu-ba-tim ${ }^{211}$ it-mu-ú.

(is Özgüç 2005, s. 9.

(2) Veenhof 2003, s. 57.

"Cecen 2002, s. 65 vd.

"Kt 83/k 129: "s) ki-ma / ma-tum "s" sì-hi it-at-mi

"Nashef 1991, s. $11 \%$. 
Ku[ša? $]^{\prime} y$ benim adıma gözetiniz ve (zira) bizim habercilerimize onlar hiçbir șey vermedi ${ }^{\text {"’? }}$.

Kültepe metinleri incelendiğinde bu dönem kraliçelerinden bazılarımın, Koloni C̣ă̆ı'nın en azından belirli dönemlerinde ve bazı şehirlerinde idarî ve hukukî kararlar alabilecek derecede ülke yönetiminde söz sahibi oldukları görülür. Belgelerde bu bayanlar ya kral ile yan yana veya tek bașlarına emrindeki idarî görevliler ile, hâkim bir güç olarak karșımıza çıkarlar. Bu yönetimsel güç, Koloni Çağı Anadolu'sunda kadının statüsünü göstermesi bakımından mühimdir.

Bu hususta vereceğimiz ilk örnek ATHE 62 nolu metindir. Belgede, kraliçenin kaçakçılık yapan Pušuken adlı Asurlu tüccarı tutuklattuğı bilgisi mevcuttur. Pušuken'in Kaniš'te ikamet etmesi sebebiyle, tüccarı tutuklatan bayanın Kanišs in kraliçesi olduğu kabul edilmekte ${ }^{74}$, bu olayın yașandığı tarih Eski Asur kralı Šarrukīn' in son dönemlerine, M.Ö. \pm 1880 yıllarına tarihlendirilmektedir ${ }^{75}$. Belgede, Kaniš kraliçesinin, Malatya ve K.Maraș arasında kalan bölgede $\operatorname{aranan}^{7 \mathrm{~T}}$ Luhuzattia, Hurama ve Šalahšua șehirleri ile ülkesindeki her yere kaçakçıllğın önlenmesi hususunda bir mektup yazdığı belirtilerek, tüccarlardan dikkatli olmalan ve kaçakçılık yapmamalanı istenmektedir. İlgili satırlarda: "onun kaçak malını Irrā'nun oğlu Pušuken'e gönderdi ve onun kaçak malı yakalandı ve saray Pušuken'i hapse attı. Nöbetçiler güçlüdür. Kraliçe, Luhuzattia, Hurama, Šalahšua ve ülkesindeki (her yere) kaçakçılıkla ilgili (mektup) yazdı. Gözlerinizi açın! Lütfen hiçbir șeyin kaçakçılığnn yapmayn" denmektedir ${ }^{77}$. Görüldüğğ gibi, Kaniš kraliçesi tüccar Pušuken'i hapse atturarak hukukî, kaçakçılığın önlenmesi hususunda yazdığı mektupla da idarî bir karar vermiștir. Kraliçe, bir kral gibi hareket etmiș, ülkesinin çıkarlarını korumak adına yetkilerini etkin șekilde kullanmıștur. Bu durum aynı zamanda Kaniš

${ }^{73} \mathrm{Kt}$ 83/k 129: ") [a-na kà-ri-im] ${ }^{2)} \mathrm{Kà-n}[$ ii-iš ?] "3) um-ma kà-ru-um ") Té-ga-ra-ma-ma ") ni-

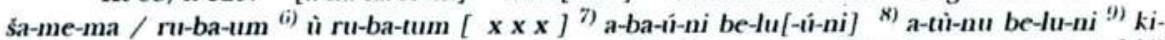
ma / ma-tum ${ }^{(1)}$ sà-hi-a-at-ni ${ }^{11)}$ a-na a-ša-ri-ku-nu ${ }^{12)}$ ni-is-pu-ra-am ${ }^{13)}$ A-šur-na-da ì Ku-sa ${ }^{\text {II }}$

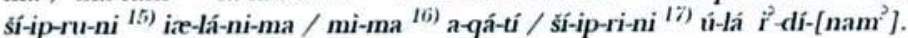

${ }^{74}$ Orlin 1970, s. 79; Darga 1976, s. 6.

75. Garelli 1963, s. 73.

7 Nashef 1991, s. 61, 79, 99.

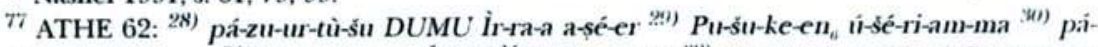

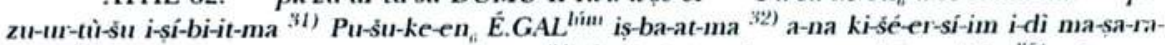

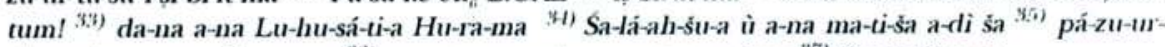
tim ru-ba-tum ta-áśspur-ma ${ }^{\text {(4) }}$ e-na-tum na-ad-a a-pu-tum mi-ma ${ }^{37)}$ lá tù-pá-za-ar. 
tahtında bir kralın olmadığımı ve ülkenin yönetiminin bir kraliçenin idaresi altunda olduğunu göstermektedir.

Kültepe metinlerinde bahsi geçen bir diğer kraliçe, genellikle bugünkü Elbistan civarında aranan ${ }^{7 \times}$ Luhuzattia șehri kraliçesidir. Tekstil ürünleriyle meșhur bu șehir, Asurlu tüccarlarm Asur'a dönüșlerinde yün aldıkları bir merkez olarak da kabul edilmektedir ${ }^{7 !}$. Belgeden, Luhuzattia kraliçesinin kalaya karşı kumaşları alıkoyduğu anlaşılmaktur. Kraliçe, muhtemelen tüccarlardan kalay getirmeleri talebinde bulunmuş, fakat bu isteğinin gerçekleşmemesi nedeniyle, tüccarların kumaşlarına el koymuştur. Kumaşlara el konulma kararının verilmesi ve bu kararın uygulanması Luhuzattia'da idarenin bir kraliçenin elinde olduğunu göstermesi bakımından mühimdir. İlgili saturlarda şu ifadeler yer almaktadır: "Sizin bana gönderdiğiniz 25 parça kutānu-kumaşı Luhuzattia'da alıkondu. (Bu nedenle) saraya çıkuk ve kraliçe şöyle söyledi: Kumaşlar kalay için tutulmaktadır. (Kalay) buraya getirin" ${ }^{\prime \prime}$.

C. Günbattı tarafından yayınlanan Kt n/k 504 nolu metin, M.Ö. II. bin'de Eski Anadolu'da hukuk anlayıșını ortaya koymasının yanında, Koloni Çağı Anadolu kraliçelerinin ülke yönetimindeki etkinliğini, hatta kral ile eşit söz hakkına sahip olduğunu göstermesi sebebiyle de son derece önemli bir belgedir ${ }^{-11}$. Metinde, Aššur-taklāku adlı Asurlu tüccarm saray tarafindan tutuklandığı, bunun üzerine kārum'dan bir heyetin Kaniš kralı ve kraliçesinin ${ }^{\$ 2}$ huzuruna çıktı̆̆ı ve meslektașlarının serbest bırakılması hususunda talepte bulundukları kayıtlıdır. Elçiler Aššur-taklāku'nun kendileri gibi bir tüccar olduğunu, her zaman kral ve kraliçenin emrinde bulunduğunu belirterek, arkadaşlarının suçsuzluğunu ispatlaması için; ya tanrı Aššur'un hançeri huzurunda yemin etmesine ya da yerli bir kimse gibi nehre gitmesine izin verilmesini istemektedirler. Kral ve kraliçe elçilerin bu isteklerinin yerine gelmesi için; düșmanları olan Tawiniya kralı adına casusluk yapan bir şahsın kendilerine teslim edilmesini veya 1 mina amūtum ya da 10 mina altun verilmesini istemişlerdir. Bu isteklerinin

${ }^{78}$ Nashef 1991, s. 79.

7.) Gökçek 2004, s. 318.

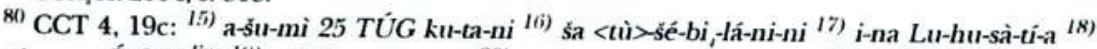
șa-áb-tù a-na É.GAL ${ }^{\text {lim }}{ }^{19)}$ né-li-ma um-ma ${ }^{20)}$ ru-ba-tum-<ma>șa-bi $i_{-}-i t^{21)}$ TÚG.HI.A <a>na AN.NA ${ }^{22)}$ i-la-kam.

${ }^{81}$ Günbattu 2000, s. 73-88.

${ }^{82}$ Günbatu a.g.m., s. 83. 
yerine getirilmemesi durumunda ise, Aššur-takläku'nun öldürüleceğini ifade etmektedirler. Her yönüyle önemli olan bu belgenin tercïmesinin tamamm vermeyi uygun görüyoruz: 'Saray Aššu-taklāku'yu yakaladıktan sonra iki ay geçti ve bir kārum (heyeti) saraya çıktı ve kral ve kraliçeye şöyle söyledi: $(O)$ adam (Ašur-taklāku) suç ișlemedi ve uygunsuz bir davranıșta bulunmadı. Adamı serbest burakın! Bizimle birlikte (bu) adam burada bir firmaya sahiptir ve bizimle beraber (her zaman) emrinize âmade olacaktur. Kral ve kraliçe şöyle cevap verdiler: Tawinia'dan gönderilmiş mektubu getiren ve düşmanım(ız)a istediği (bilgiyi) taşıyacak olan başımızı araștıracak olan (kimseyi) buraya getirin ve kardeşiniz (Aššurtaklāku) serbest kalsın. Kārum şöyle dedi: $O$ (Aššır-taklāku) hazır olsun (ve) tanrı Aššur'un hançeri üzerine yemin etsin veya sizin şehrinizin bir yerlisi gibi (aklanmak için) nehre gitsin! Hiçbir șekilde alış-veriş yapmadığına ve Tawiniya'ya (herhangi bir şey) götürmediğine; Tawiniyalı (kralın) istediğini yerine getirmeyecek! Kral ve kraliçe şöyle cevap verdiler: Elimizde tuttuğumuz bir tableti yemin için size göndereceğiz, adamı buraya getirin! Eğer adamı getirmezseniz, 1 mina amūtum veya 10 mina altun verin ve kardeşiniz (Aššur-taklāku) serbest kalsın. Eğer (bu istediklerimizi) bize vermezseniz; fikrinizi değiștirmez ve onun adını söylemezseniz, kardeșiniz ölmüștür (onu ölü bilin!) Asur șehrinin tableti gereğince, Kaniš kārumu('nun) küçük (ve) büyük (meclisleri) bizi (șahit olarak) belirledi ve tanrı Ašur'un hançeri önünde (șahitliğimiz hakkındaki) tableti verdik. Amur-Ǎššr'un huzurunda, Usur-ša-Ištar'in huzurunda, IdīAššru'un huzurunda, Buzazu'nun huzurunda ${ }^{* 3}$. Görüldüğgü üzere;

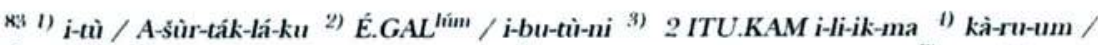
a-na É.GAL lim 5) e-li-ma um-ma kà-ru-um-ma "i) a-na ru-ba-im ù ru-ba-tim-ma 7) a-wi-lúm ar-

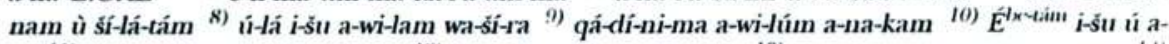
na ${ }^{11)}$ e-ri-iš-tí-ku-nu qá-di-ni-ma (2) i-za-az um-ma ru-ba-ım 13) ú ru-ba-tum-ma mu-še-bi-il, (i) xup-pì-im ša iš-tù Ta-wi-ni-a ${ }^{15)}$ ú-šé-bi,-lá-ni-ma e-ri-iš-tám ${ }^{\text {li) }}$ a-na be-el nu-ku-ur-ti-a i-za-bi-lu 17) ú qá-qí-dí i-śé-e-ú ${ }^{18)}$ ru-a-nim-ma ú a-hu-ku-nu lu-šéer ${ }^{19)}$ um-ma kà-ru-um-ma li-zi-iz ${ }^{20)}$ GÍR ša A-šur li-it-ma ${ }^{21)}$ ú-ul ki-ma DUMU a-li-kà ${ }^{22)}$ a-na i-id li-li-ik ${ }^{23)}$ ši-ma-am mi-ma lá iš-úmu-ma ${ }^{21)}$ a-na Ta-wi-ni-a ${ }^{25)}$ lá ú-sé-bi,-lu a-na ru-ba-im ${ }^{26)}$ Ta-wi-ni-a-i-im 27) a-na e-ri-iš-tí-šu ${ }^{28)}$ lá i-za-zu-ni ú-ul né-nu ${ }^{29)}$ a-pu-hi-šu GíR ša A-šur ${ }^{\text {ko) }}$ In ni-it-ma a-hu-ni ${ }^{31)}$ a-na e-ri-iš-tí Ta-

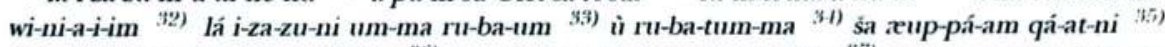
ù-kà-lu ku-nu-tí a-na ma-mi-tim ${ }^{36)}$ a-ra-de -ku-nu a-wi-lam ru-a-nim ${ }^{37)}$ šu-ma a-wi-lam lá ta-ra-

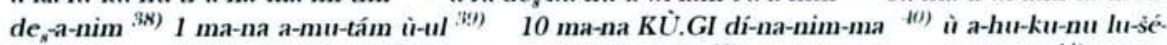

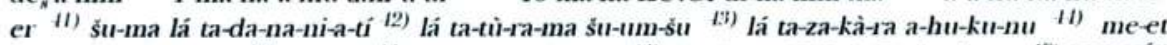
a-ma-lá ceup-pi-im ${ }^{15)}$ Ša a-lim ki kà-ru-ım Kà-ni-iš (i) Ha-he-er GAL i-di-ni-a-ti-ma (7) IGI GIR

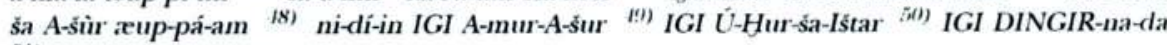
5i) IGI I-di-A-šìr IGI Bu-za-zu. 
- Kärum heyeti saraya çıktıklarunda kral ve kraliçeye ricada bulunmaktadırlar.

- Kärum heyetinin taleplerine kral ve kraliçe birlikte yanıt vermektedir ler.

- Kral ve kraliçe tutuklunun serbest kalabilmesi için yerine getirilmesi gereken șartlan birlikte suralamaktadırlar.

Metindeki bu tür ifadeler, kral ve kraliçenin ortak söz hakkı bulunduğunu göstermektedir. Öyle ki, ülke güvenliğini ilgilendiren bir meselede dahi kraliçenin bu denli etkin bir pozisyona sahip olması, bu dönem Anadolu kraliçelerinin siyasi güçlerini göstermesi bakımundan önemlidir.

Koloni Çağı'nda Anadolu halkının sosyal yașantısı hakkında kesin bilgilere sahip değiliz. Bu durum, Anadolu kadınm en üst seviyede temsil eden kraliçeler için de geçerlidir. Civi yazılı belgeler Anadolu șehirlerinden Amkuwa, Hattuš, Kaniš, Kuburnat, Luhuzattia, Tawinia, Tegarama, Timelkia ve Wahšušana kraliçeleri hakkmnda az ama önemli bilgiler vermektedir. Bu bayanları, günlük hayatta veya bir eș ya da anne olarak değerlendirebileceğimiz kesin bilgiler de mevcut değildir. Sadece, Asurlu tüccarlara verdikleri kumaș ve elbise siparișlerinden, bakımlı birer kadın olduklarmı söyleyebiliriz. Bu bilgi kısırlığına rağmen, isimlerini tespit edemediğimiz bu kraliçeler, bazen kral ile birlikte, bazen de tek bașlarma; ülkelerinin çıkarlarmı ön planda tutan, idari vetkilerini en etkin șekilde kullanan, hukukî kararlar veren ve ülke yönetiminde söz sahibi olan yönetici bayanlar olarak karșımıza çıkmaktadırlar. Belgelerde, gümüș ve kalay ile birlikte anılmaları sebebiyle, ticari faaliyetlerde bulundukları düşünülen ${ }^{* 1}$ kraliçeler, dini törenlere katılmakta, kral ile birlikte yemin de etmektedirler. Yerel halk için son derece önemli olan bu günlerde, kralın yanmda bulunmaları, hatta birlikte bazı ritüelleri yerine getirmiș olmaları, konumlarmm önemini göstermektedir. Sonuç olarak, Koloni Cağı'nm en azından belirli dönemlerinde ve bazı şehirlerinde bu bayanlarm çok etkin ve güçlü oldukları anlașıılmaktadır.

${ }^{\times 1}$ Darga 1976, s. 7. 


\section{BİBLIYOGRAFYA}

AHw, Akkadisches Handwörterbuch.

Albayrak, İ. 1998: "Koloni Cağnnda Yerli Bir Bayan Madawada”, III. Uluslararası Hititoloji Kongresi. Ankara, s. 1-14.

2000: "Kültepe'den Yeni Bir Vasiyetnâme", Archivum Anatolicum 4, Ankara, s. 1-16.

Alp, S. 2001: Hitit Cağında Anadolu, TüBİTAK Popüler Bilim Kitapları. İstanbul.

ATHE, Die altassyrischen Texte des Orientalischen Seminars in Heidelberg und der Sammlung Erlenmeyer.

Balkan, K 1957: Mama Kralı Anum-Hirbi'nin Kaniš Kralı Warshama'ya Gönderdiği Mektup, Türk Tarih Kurumu VII/31. Ankara.

Bayram, S. 1991: "Tașınmaz Mallar Hakkında Yeni Kültepe Vesikaları”, Belleten 55 / 213, Ankara, s. 297-314.

1994: "Kültepe Metinlerinde Geçen Yeni Yer Adları ve Bunların Değerlendirilmesi”, XI. Türk Tarih Kongresi, Ankara, s. 211-234.

Bayram, S.-Ceçen, S. 1997: "Yeni Belgelerin Ișı̆̆ında Eski Anadolu'da Kölelik Müessesesi”, Belleten LX, Ankara, s. 579-630.

BIN, Babylonian Inscription in the Collection of J. B. Nies.

Ceçen, S. 2002: "Kültepe Belgelerine Göre Anadolu Şehir Devletlerinde Ayaklanma", Archivum Anatolicum 5, Ankara, s. 65-68.

Darga, M. 1976: Eski Anadolu'da Kadın, İstanbul Üniversitesi Edebiyat Fakültesi Yaynnları, İstanbul.

Dercksen, J. G. 2005: "Adad is king! The Sargon text from Kültepe", JEOL 39 , s.107-129.

Donbaz, V. 2001: “Some Recently Discovered Karum 1-b Tablets and Related Observations”, IV. Internationalen Kongresses für Hethitologie, Weisbaden, 106-114.

Garelli, P. 1963: Les Assyriens en Cappodoce, Paris.

Gökçek, G. L. 2002: Koloni Devri Anadolu'sunda Asurlu Tüccar Aileler, Yayımlanmamıș Doktora Tezi, Gazi Üniversitesi Sosyal Bilimler Enstitüsü. Ankara. 
2004: "Kültepe Tabletlerinde Maras Bölgesi”, I. Kahramanmaras Sempozyumu, Kahramanmaraș, s. 309-318.

Günbatt, C. 1994: "Kültepe Tabletlerine Göre Kadmlarm Ticari Faaliyetleri Hakkında Bazı Gözlemler", XI. Türk Tarih Kongresi, Ankara, s. 191-200.

1996: "Two New Tablets Throwing Light on the Relations Between Anatolian Kings and Assyrian Merchants in the Period of the Assyrian Colonies", Archivum Anatolicum 2, Ankara, s. 25-37.

2000: "Eski Anadolu'da Su Ordali", Archivum Anatolicum 4, A. ̈̈. Basımevi, Ankara, s. 73-88.

ICK, Inscriptions Cunéiformes du Kultépé.

Michel, C. 2003: "The perdum-mule, a Mount for Distinguished Persons in Mesopotamia During the First Half of the Second Millennium B.C.", in B. Frizell (ed.) PECUS. Man and Animal in Antiquity, Roma, s. 190-200.

Nashef, Kh. 1991: Die Orts- und Gewässernamen der altassyichen Zeit. (Réportoire Géographique des Textes Cunéiformes Bd. 4). Weisbaden.

OIP, Oriental Institute Publications.

Orlin, L. L. 1970: Assyrian Colonies in Cappadocia. Paris.

Özgüç, T. 2005: Kültepe Kaniš/Neša, Yapı Kredi Yayınlaıı. İstanbul.

Sugiyama, T 1997: "Trading perdum and its aspects in the Old Assyrian Period", Oriento 42, s. 139-154.

Ulshöfer, A. M. 1995: Die Altassyrischen Privaturkunden. Stutgart.

Veenhof, K. R. 2003: The Old Assyrian List of Year Eponyms From Karum Kanish And Its Chronological Implications. Türk Tarih Kurumu VI/64. Ankara.

Veenhof, K.R. 2006: "Traveling in Ancient Anatolia: Two New sources from Karum Kanesh”, Hayat Erkanal'a Armağan, Kültürlerin Yansıması, Homer Kitabevi, Ankara, s.778-783. 
